\title{
ЦИЛИАТНОЕ НАСЕЛЕНИЕ АЭРОТЕНКОВ ОЧИСТНЫХ СООРУЖЕНИЙ Г. ХАБАРОВСКА
}

\section{CILIATE POPULATION OF AERATION TANKS OF KHABAROVSK TREATMENT FACILITIES}

M. Tribun

A. Zhukov

Summary. The paper presents data on the fauna of ciliates of wastewater treatment plants in Khabarovsk. It was found that the ciliocenosis of the studied aerotanks includes 57 species belonging to 2 subtypes and 8 classes. The trophic structure is dominated by bacterio-detritophages $(72 \%)$, while the ecotopic structure is dominated by the periphyton and periphyton-benthic groups.

Keywords: infusorians, ciliofauna, activated sludge, wastewater, sewage treatment plants.

\author{
Трибун Михаил Маркович \\ К.б.н., доцент, Дальневосточный государственный \\ университет путей сообщения, г. Хабаровск \\ tribunmikhail@gmail.com \\ Жуков Андрей Валерьевич \\ К.б.н., директор, Амурский институт \\ железнодорожного транспорта, г. Свободный \\ a.v.zhukov@mail.ru
}

Аннотация. В работе приводятся данные по фауне инфузорий очистных станций г. Хабаровска. Установлено, что цилиоценоз исследованных аэротенков насчитывает 57 видов, относящихся к 2 подтипам и 8 классам. В трофической структуре преобладают бактерио-детритофаги (72\%), а в экотопической - перифитонная и перифитонно-бентосная группы.

Ключевые слова: инфузории, цилиофауна, активный ил, сточные воды, очистные сооружения.

мации и минерализации органических веществ и энергии [2-5].

\section{Шель работы}

Получение новых данных по фауне и экологии цилиата очистных сооружений г. Хабаровска.

В плане реализации цели нами были определены следующие задачи исследования:

1. Инвентаризация видового состава цилиатного населения очистных сооружений г. Хабаровска.

2. Осуществить сравнительный зоогеографический анализ видового сходства цилиоценозов различных регионов.

3. Выявить некоторые эколого-биологические характеристики инфузорий активного ила.

4. Установить индикационную роль цилиофауны в процессе очистки сточных вод.

\section{Мето икка сбора и обработки материала}

Материалом для настоящего исследования послужили водные образцы, отобранные из аэротенков очист- 
ных сооружений в период 2009-2012 гг. и 2018-2020 гг. Было проанализировано на предмет выявления инфузорий свыше 300 проб.

Очистные сооружения г. Хабаровска, располагающиеся вблизи пос. Березовка, были запущены в эксплуатацию в 1983 году. Очистка сточных вод ведется по классической схеме - механическая, полная биологическая очистка и обеззараживание жидким хлором. Общий объем стоков города Хабаровска составляет, ориентировочно, 300 тыс. м³/сут., из них проходят полную механическую и биологическую очистку 220,2 тыс. м³/сут. стоков, а остальные сбрасываются неочищенными [4].

Отбор гидробиологического материала осуществлялся при помощи пробоотборников, в качестве которых использовали стеклянные (реже полиэтиленовые) широкогорлые сосуды объемом не более 500 мл. В периоды обедненного видового богатства инфузорий, образцы предварительно центрифугировали (1500 об/мин на 30-60 сек) или отстаивали, а также добавляли питательную среду. В качестве питательного субстрата чаще всего использовали сенной отвар [6-8]. Для его приготовления в коническую колбу на 2/3 объема наливали сырой воды и добавляли 100-200 г мелко нарезанного сена сорных трав: клевера полевого, овса, тимофеевки луговой, листьев деревьев. Далее полученную смесь кипятили в течение 20 минут.

Изучение цилиата производили in vivo и in vitro с использованием микроскопов фирм «Leica» (Германия), «Motic» (Гонконг), «Микмед-6» (Россия). Прижизненное наблюдение за инфузориями производили с применением технологии «микроаквариумов» [9-10]. Для этого припаровальной иглой на углах покровного стекла делали небольшие вазелиновые ножки. Далее этим стеклом накрывали каплю исследуемой жидкости. Для длительного наблюдения «микроаквариум» помещали в чашку Петри, на дно которой укладывали слегка смоченную водой фильтровальную бумагу.

Выявление видового состава цилиата активного ила производили с помощью метода «стекло по стеклу». На одном предметном стекле равномерно распределяли иловую смесь. Второе стекло ставили на первое узкой стороной (под углом около $45^{\circ}$ ), вплотную к краю пробы. Далее, вторым стеклом аккуратно сдвигали активный ил к противоположному краю, а первое стекло немного наклоняли, чтобы отделить воду с протистами от хлопьев ила [11]. Для снижения двигательной активности клеток простейших применяли фиксаторы Да-Фано и Карнуа [12].

Видовая идентификация инфузорий производилась с использованием определителей, а также многочис- ленных описаний, изложенных в специализированных монографиях и статьях [4,6,8,13-18]. Распределение цилиата по трофическим группам, экотопической приуроченности и индикационному значению осуществлялось согласно работ $[19,20]$.

Для проведения зоогеографического анализа использовались доступные литературные сведения по цилиоценозу аэротенков следующих населенных пунктов: г. Свободный, пос. Говсана и Сахиль, г. Вельс и г. Борисоглебск [21-24].

При сравнительном анализе группировок цилиата применялся коэффициент фаунистического сходства Чекановского-Серенсена, вычисляемый по формуле:

$$
I_{C S}=\frac{2 C \times 100}{A+B}
$$

где, C - число видов, общих для двух сравниваемых биотопов; А - число видов, населяющих первый объект; В - то же, во втором.

\section{Результаты и обсужление}

В ходе фаунистической ревизии было выявлено 57 видов инфузорий, относящихся к 2 подтипам и 8 классам (табл. 1). Основу цилиатного населения представляют виды класса Oligohymenophorea, насчитывающий 26 представителей, что составляет 45,6\% от общего разнообразия инфузорий аэротенков очистных сооружений г. Хабаровска. Наибольшее число видов отмечено в родах Epistylis и Vorticella (по 7).

Достаточно широко в очистных станциях представлены инфузории подкласса Peritrichia. К данному таксону был отнесен 21 вид, что составляет 37\% от всего видового богатства цилиата исследованных аэротенков. Обильное развитие перитрих отмечается на стенках резервуаров, поверхности хлопьев активного ила и прочих субстратах. Массовая колонизация пространства характерна, в-первую очередь, для представителей родов Epistylis и Vorticella.

Коэффициент видового сходства цилиофауны между аэротенками г. Хабаровска и другими очистными сооружениями оказался достаточно низким: г. Свободный - 31\%, пос. Говсана и Сахиль - 24,7\%, г. Борисоглебск - 21\% и г. Вельс - 35,6\%. Данное обстоятельство указывает на формирование уникальных условий для жизнедеятельности цилиоценоза присущих каждым очистным станциям. Согласно литературным данным [2, 25], главная роль в этом процессе принадлежит абиотическим и биотическим экологическим факторам. Среди которых важнейшее значение имеют температурный режим и обилие пищи. 
Таблица 1. Таксономический состав и некоторые эколого-биологические характеристики цилиоценоза очистных сооружений г. Хабаровска

\begin{tabular}{|c|c|c|c|}
\hline Вид & Трофическая группа & Экотопическая группа & $\begin{array}{l}\text { Индикационное } \\
\text { значение }\end{array}$ \\
\hline \multicolumn{4}{|l|}{ Тип Ciliophora Doflein, 1901} \\
\hline \multicolumn{4}{|c|}{ Подтип Postciliodesmatophora Gerasimova, Seravin, 1976} \\
\hline \multicolumn{4}{|c|}{ Класс Heterotrichea Stein, 1859} \\
\hline $\begin{array}{l}\text { Blepharisma lateritium (Ehrenberg, } \\
\text { 1831) }\end{array}$ & Б-Д & E & - \\
\hline $\begin{array}{l}\text { Stentor coeruleus } \\
\text { (Pallas, 1766) }\end{array}$ & $\mathrm{H}$ & Пл, Пр, Б & - \\
\hline $\begin{array}{l}\text { S. roeseli } \\
\text { Ehrenberg, } 1835\end{array}$ & $\mathrm{H}$ & Пл, Пр, Б & - \\
\hline $\begin{array}{l}\text { Spirostomum minus } \\
\text { Roux, } 1901\end{array}$ & Б-Д & B & - \\
\hline S. teres Claparede et Lachmann, 1859 & Б-Д & B & - \\
\hline \multicolumn{4}{|l|}{ Подтип Intramacronucleata Lynn, 1996} \\
\hline \multicolumn{4}{|l|}{ Класс Spirotrichea Butschli, 1889} \\
\hline $\begin{array}{l}\text { Aspidisca cicada } \\
\text { (Muller, 1786) }\end{array}$ & Б-Д & Пр, Б & $\begin{array}{l}\text { Низкие значения БПК } 5 \text { и ХПК, } \\
\text { мало растворенного кислорода } \\
\text { и нитратов }\end{array}$ \\
\hline $\begin{array}{l}\text { A. turrita } \\
\text { (Ehrenberg, 1838) }\end{array}$ & Б-Д & Пр, Б & 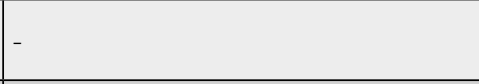 \\
\hline $\begin{array}{l}\text { Euplotoides patella } \\
\text { (Muller, 1773) }\end{array}$ & Б-Д & $\Pi p$ & $\begin{array}{l}\text { Нормальный режим работы. При } \\
\text { массовом развитии совместно } \\
\text { с коловратками свидетельствует } \\
\text { об улучшении процесса очистки }\end{array}$ \\
\hline Oxytricha fallax Stein, 1859 & Б-Д & Б & - \\
\hline Tachysoma pellionellum (Muller, 1773) & $\mathrm{H}$ & Пл, Пр, Б & - \\
\hline \multicolumn{4}{|l|}{ Класс Armophorea Lynn, 2002} \\
\hline Caenomorpha medusula Perty, 1852 & Б-Д & E & - \\
\hline Metopus es Muller, 1786 & Б-Д & E & $\begin{array}{l}\text { Перегруженый ил, низкое } \\
\text { содержание О } 2 \text { в воде }\end{array}$ \\
\hline Metopus sp. & Б-Д & E & - \\
\hline \multicolumn{4}{|l|}{ Класс Litostomatea Small et Lynn, 1981} \\
\hline Acineria uncinata Tucolesco, 1962 & Б-Д & $\Pi p$, Б & $\begin{array}{l}\text { Здоровый активный ил, } \\
\text { нормальный режим работы }\end{array}$ \\
\hline Amphileptus pleurosigma Stokes, 1884 & $x$ & $\Pi p$ & \begin{tabular}{|l} 
Встречается при невысокой \\
и средней нагрузке на активный ил
\end{tabular} \\
\hline Amphileptus sp. & $x$ & $\Pi p$ & - \\
\hline $\begin{array}{l}\text { Litonotus carinatus } \\
\text { Stokes, } 1885\end{array}$ & $x$ & $\Pi p$, Б & - \\
\hline L. lamella (Muller, 1773) & $x$ & $\Pi p$, Б & $\begin{array}{l}\text { Повышенная нагрузка на ил, } \\
\text { нарушение процесса очистки }\end{array}$ \\
\hline Spathidium sp. & Б-Д & Пл & - \\
\hline \multicolumn{4}{|c|}{ Класс Phyllopharyngea Puytorac et al., 1974} \\
\hline Acineta tuberosa Ehrenberg, 1834 & $x$ & $\Pi p$ & - \\
\hline Chilodonella uncinatus Ehrenberg, 1838 & Б-Д & $\Pi p$, Б & - \\
\hline $\begin{array}{l}\text { Dendrosoma radians } \\
\text { Ehrenberg, } 1837\end{array}$ & $x$ & $\Pi p$ & - \\
\hline $\begin{array}{l}\text { Discophrya elongata } \\
\text { Claparede et Lachmann, } 1859\end{array}$ & $x$ & $\Pi p$ & - \\
\hline Sphaerophrya sol Metshnikoff, 1864 & $x$ & $\Pi p$ & - \\
\hline $\begin{array}{l}\text { Tokophrya mollis } \\
\text { Butschli, } 1889\end{array}$ & $x$ & Пр, Эпб & - \\
\hline
\end{tabular}


Таблица 1 (продолжение). Таксономический состав и некоторые эколого-биологические характеристики цилиоценоза очистных сооружений г. Хабаровска

\begin{tabular}{|c|c|c|c|}
\hline Вид & Трофическая группа & Экотопическая группа & $\begin{array}{l}\text { Индикационное } \\
\text { значение }\end{array}$ \\
\hline $\begin{array}{l}\text { T. quadripartita } \\
\text { Claparede et Lachmann, } 1859\end{array}$ & $x$ & Пр, Эпб & 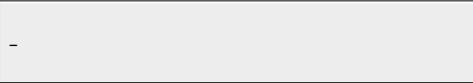 \\
\hline $\begin{array}{l}\text { Trichophrya brevis (Goodrich et Jahn, } \\
\text { 1943) }\end{array}$ & $x$ & $\Pi p$ & - \\
\hline $\begin{array}{l}\text { Trithigmostoma cucullus Jankowski, } \\
1967\end{array}$ & A & Пр, Б & $\begin{array}{l}\text { Чувствителен к фосфатному } \\
\text { загрязнению }\end{array}$ \\
\hline \multicolumn{4}{|l|}{ Класс Nassophorea Small et Lynn, 1981} \\
\hline Microthorax pusillus Engelmann, 1862 & Б-Д & Б & - \\
\hline $\begin{array}{l}\text { M. sulcatus } \\
\text { Engelmann, } 1862\end{array}$ & Б-Д & Пр, Б & - \\
\hline \multicolumn{4}{|l|}{ Класс Prostomatea Small\&Lynn, 1985} \\
\hline Coleps hirtus Nitzsch, 1817 & $\Gamma$ & Пл, Пр, Б & $\begin{array}{l}\text { Невысокая нагрузка на активный } \\
\text { ил, устойчив к низкому } \\
\text { содержанию } \mathrm{O}_{2}\end{array}$ \\
\hline \multicolumn{4}{|c|}{ Класс Oligohymenophorea De Puytorac et al., 1974} \\
\hline $\begin{array}{l}\text { Carchesium batorligetiense } \\
\text { Stiller, } 1953\end{array}$ & Б-Д & $\Pi p$ & - \\
\hline $\begin{array}{l}\text { C. polypinum } \\
\text { (Linnaeus, 1758) }\end{array}$ & Б-Д & $\Pi p$ & - \\
\hline Colpidium campylum Stokes, 1886 & Б-Д & Пл, Б & Низкая и средняя нагрузка на ил \\
\hline $\begin{array}{l}\text { Cothurnia imberbis } \\
\text { Ehrenberg, } 1831\end{array}$ & Б-Д & $\Pi p$ & - \\
\hline Epistylis bimarginata Nenninger, 1948 & Б-Д & $\Pi p$ & Низкая и средняя нагрузка на ил \\
\hline $\begin{array}{l}\text { E. chrysemidis } \\
\text { Bishop et Jahn, } 1941\end{array}$ & Б-Д & $\Pi p$ & 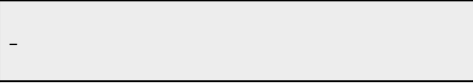 \\
\hline E. epibioticum Banina, 1983 & Б-Д & Эпб & - \\
\hline $\begin{array}{l}\text { E. longicaudatum } \\
\text { Banina, } 1983\end{array}$ & Б-Д & $\Pi p$ & - \\
\hline E. polenici Matthes, 1950 & Б-Д & $\Pi p$ & - \\
\hline $\begin{array}{l}\text { E. plicatilis } \\
\text { Ehrenberg, } 1831\end{array}$ & Б-Д & $\Pi p$ & - \\
\hline $\begin{array}{l}\text { E. thienemanni } \\
\text { (Nenninger, 1948) }\end{array}$ & Б-Д & Пр, Эпб & - \\
\hline $\begin{array}{l}\text { Opercularia coarctata } \\
\text { (Claparede et Lachmann, 1858) }\end{array}$ & Б-Д & Пр, Пл & Высокая токсичность сточных вод \\
\hline $\begin{array}{l}\text { O. curvicaulis } \\
\text { (Penard, 1922) }\end{array}$ & Б-Д & Пр, Пл & $\begin{array}{l}\text { Индикатор наличия в воде } \\
\text { сероводорода } \mathrm{H}_{2} \mathrm{~S}\end{array}$ \\
\hline O. phryganae Kahl, 1935 & Б-Д & $\Pi p$ & $\begin{array}{l}\text { Индикатор наличия в воде } \\
\text { сероводорода } \mathrm{H}_{2} \mathrm{~S}\end{array}$ \\
\hline Paramecium caudatum Ehrenberg, 1833 & Б-Д & Пл, Б & $\begin{array}{l}\text { Высокая нагрузка на ил и/или } \\
\text { дефицит растворенного кислорода }\end{array}$ \\
\hline $\begin{array}{l}\text { Tetrahymena pyriformis complex } \\
\text { Schewiakoff, } 1889\end{array}$ & Б-Д & Пр, Б & $\begin{array}{l}\text { «Молодой» активный ил, индикатор } \\
\text { анаэробных условий }\end{array}$ \\
\hline Urocentrum turbo Nitzsch, 1827 & Б-Д & $\Pi p$, Б & - \\
\hline Uronema marinum Dujardin, 1841 & Б-Д & Пр, Б & Низкое качество сточных вод \\
\hline $\begin{array}{l}\text { Vorticella alba } \\
\text { Fromentel, } 1876\end{array}$ & Б-Д & $\Pi p$, Б & Активный ил разной нагрузки \\
\hline V. convallaria (Linne,1767) & Б-Д & $\Pi p$ & $\begin{array}{l}\text { Здоровый активный ил, } \\
\text { нормальный режим работы }\end{array}$ \\
\hline $\begin{array}{l}\text { V. infusionum } \\
\text { Dujardin, } 1841\end{array}$ & Б-Д & $\Pi p$ & $\begin{array}{l}\text { Индикатор наличия в воде } \\
\text { сероводорода } \mathrm{H}_{2} \mathrm{~S}\end{array}$ \\
\hline
\end{tabular}


Таблица 1 (продолжение). Таксономический состав и некоторые эколого-биологические характеристики цилиоценоза очистных сооружений г. Хабаровска

\begin{tabular}{|l|l|l|l|}
\hline Вид & Трофическая группа & Экотопическая группа & $\begin{array}{l}\text { Индикационное } \\
\text { значение }\end{array}$ \\
\hline $\begin{array}{l}\text { V. microstoma } \\
\text { Ehrenberg, } 1830\end{array}$ & Б-Д & Пр & $\begin{array}{l}\text { Индикатор наличия в воде } \\
\text { сероводорода Н } 2 \text { S }\end{array}$ \\
\hline V. nutans Muller, 1773 & Б-Д & Пр & - \\
\hline V. octava Stokes, 1885 & Б-Д & Пр & - \\
\hline $\begin{array}{l}\text { V. submicrostoma } \\
\text { Ghosh, 1922 }\end{array}$ & Б-Д & Пр & - \\
\hline Zoothamnium procerius Kahl, 1935 & Б-Д & Пр & Хорошая эффективность Очистки \\
\hline
\end{tabular}

Примечание:

трофическая группа: б-д - бактерио-детритофаг, г - гистофаг, х - хищник, а - альгофаг, н - неселективный (всеядный).

экотопическая группа: пл — планктонная, пр - перифитонная, б - бентосная, эпб - эпибионтная.

Однако, ядро цилиосообщества в очистных сооружениях г. Хабаровска оказывается единым для большинства аэротенков разных регионов мира. К таким видам можно отнести следующих представителей: Coleps hirtus, Paramecium caudatum, Litonotus lamella, Vorticella convallaria, V. microstoma, Aspidisca cicada, Uronema marinum и др. Этот факт объясняется эврибионтностью значительной части видового состава инфузорий. Кроме того, указанные выше виды часто регистрируются и в естественных водотоках г. Хабаровска и его окрестностей $[8,26]$.

Тем не менее, несмотря на идентичность структурообразующих видов цилиоценоза, именно аэротенки очистных сооружений отличаются высокой специфичностью обитающих в них инфузорий. Так, при сравнении полученных сведений с данными по Среднему Приамурью [27] мы зафиксировали 26 «специфичных» видов, т.е. присущих только биоценозу очистных станций. Для сравнения, число таких видов в природных водотоках составляет: рр. Амур и Красная - 4; р. Черная - 1; р. Березовая - 3. Причиной специфичности цилиофауны аэротенков является стенобионтность по отношению к ряду экологических факторов: концентрация растворенного в воде кислорода и высокое гидростатическое давление для представителей подкласса Suctoria [4]; наличие течения для Peritrichia [1].

При анализе данных по приуроченности инфузорий к различным экологическим зонам водного объекта мы руководствовались следующими правилами:

- обычно, при небольшой глубине водоема деление на предпочитаемый экотоп носит условный характер, что, например, отражается в появлении бентосных видов в планктонных пробах;

- все виды перифитона, встречающиеся в обрастаниях, разделены на следующие группы: прикре- пленные («истинно перифитонные»); подвижные перифитонно-бентосные («типичные»); подвижные планктонно-бентосные («случайные») [28];

- к категории «переходные» отнесли все виды, регистрировавшиеся нами в нескольких экологических зонах биотопа [19];

Учитывая вышеизложенные особенности, а также особые условия местообитания цилиофауны, нами были получены закономерные результаты: подавляющее большинство видов колонизируют перифитонный (24 вида) и перифитонно-бентосный (12) экотопы. Суммарно к двум группам относится свыше 63\% от общего фаунистического разнообразия инфузорий в аэротенках очистных сооружений г. Хабаровска. Однако если учитывать, что каждый вид, населяющий два и более экотопа относится к «переходным», то деление на предпочитаемые экологические зоны выглядит следующим образом: бентос - 8, перифитон - 28 (включая эпибионтные формы), планктон - 1, «переходная» -20 .

Трофическая структура цилиатного населения аэротенков оказалась достаточно простой: 72\% всех выявленных видов относятся к бактерио-детритофагам и 19,2\% к группе хищников. На долю остальных категорий приходилось от 1,7 до 5,2\% от общего фаунистического разнообразия инфузорий очистных станций.

По данным [29] бактерио-детритофаги играют существенную роль в механизме очистки сточных вод. При нормальной работе аэротенков число патогенных микроорганизмов снижается на 98\%. Кроме того, в результате выедания бактерий значительно снижается мутность воды.

Из общего фаунистического списка 21 вид является показательным (индикаторным) при определении режи- 
ма работы очистных сооружений и/или наличия в среде некоторых химических веществ. Анализируя представленные данные по индикационной значимости инфузорий в аэротенках, был выявлен ряд признаков работы очистных сооружений г. Хабаровска:

- восемь представителей цилиосообщества (38\% от всего видового состава показательных видов) аэротенков являются индикаторами низкой и средней нагрузки на активный ил, т.е. показателями нормального режима работы;

- четыре вида (19\%) индексировали низкую концентрацию растворенного в воде кислорода и перегрузку ила, а три представителя - (14,2\%) наличие в среде сероводорода.

\section{Зак^ючение}

Таким образом, фауна инфузорий аэротенков очистных сооружений г. Хабаровска представлена 57 видами, ядро которых (45,6\%) относится к классу Oligohymenophorea. Проведенный зоогеоррафический сравнительный анализ цилиатного населения аэ- ротенков разных регионов мира показал достаточно низкие значения видовой общности (24,7-35,6\%), что свидетельствует об уникальности условий местообитания в каждом водоеме и, как следствие, формирование стенотопного цилиоценоза. Тем не менее, ядро структурообразующих представителей (Coleps hirtus, Paramecium caudatum, Aspidisca cicada, Uronema marinum и др.) является типичным для подавляющего большинства не только антропогенно трансформированных, но и естественных водных объектов.

По приуроченности к основному экотопу большинство видов предпочитает перифитонную (24 представителя) и перифитонно-бентосную (12) зоны, что составляет свыше 63\% от всей фауны инфузорий в исследованных аэротенках. Трофическая структура цилиоценоза очистных станций оказалась простой, с ярким доминированием бактерио-детритофагов (72\% от общего фаунистического богатства видов). Установлено, что некоторые виды цилиата являются индикаторными при определении режима работы аэротенков и служат показателями качества очистки сточных вод.

\section{ЛИТЕРАТУРА}

1. Банина Н. Н. Сіliata в очистных сооружениях бытовых и смешанных сточных вод // Протозоология: Простейшие активного ила. Л.: Наука, 1983. Вып. 4. C. 76-86.

2. Бурковский И. В. Экология свободноживущих инфузорий. Москва: МГУ, 1984. 208 с.

3. Константиненко Л. А. Круговійчасті инфузории (Сiliophora, Peritrichia) очистительных сооружений: дис. ... канд. биол. наук: 03.00.08. Житомир, 2008. 217 с.

4. Жуков А. В. Эколого-биологические особенности и индикационное значение цилиофауны очистных сооружений г. Хабаровска: дис. ... канд. биол. наук: 03.02.08. Хабаровск, 2012. 150 c.

5. Caron D.A., Joel C. G., Dennette M. R. Experimental demonstration of the roles of bacteria and bacterivorous protozoa in plankton nutrient cycles // Hydrobiology, 1998. Vol.1. P. 27-40.

6. Никитина Л. И. Инфузории Среднего Приамурья.—Хабаровск: ХГПУ, 1997.102 с.

7. Мячина 0. А. Фауна и биолого-экологические особенности ресничных инфузорий некоторых водоемов южной лесостепи Омской области: дис. ... канд. биол. наук: 03.00.04. Омск, 2010. 166 с.

8. Трибун М. М. Экологические особенности цилиофауны малых рек окрестностей г. Хабаровска: дис. ... канд. биол. наук: 03.02.08.— Хабаровск: ДВГУПС, 2012.154 c.

9. Dragesco J., Dragesco-Kerneis A. Cilies libres de l'Afrique intertropicale. Introduction a la connaissance et a l'etude des cilies // Faune tropicale. 1986. № 6. P. 1-59.

10. Berger H., FoissnerW. Illustrated guide and ecological notes to ciliate indicator species (Protozoa, Ciliophora) in running waters, lakes and sewage plants. Biologische Methoden der Gewasseranalysen, 2003. $160 \mathrm{p}$.

11. Kreutz M., Foissner W. The Sphagnum ponds of Simmelried in Germany: a biodiversity hot-spot for microscopic organisms. Protozool. Monogr., 2006. $267 \mathrm{p}$.

12. Алекперов И. Х. Атлас свободноживущих инфузорий. Баку, 2005. 310 c.

13. Curds C. British and other freshwater ciliated protozoa. Part I: Kinetofragminophora. London: Cambridge, 1982. 387 p.

14. Curds C., Gates M., Roberts D. British and other freshwater ciliated protozoa. Part Il: Oligohymenophora and Polyhymenophora. London: Cambridge, 1983. 314 p.

15. Warren A. The ecology, morphology and taxonomy of freshwater Peritrich ciliates: Thesis submitted for the degree of Doctor of Philosophy in the University of Surrey, $1983.328 \mathrm{p}$.

16. Фауна аэротенков: атлас / отв. ред. Л. А. Кутикова. Л.: Наука, 1984. 264 с.

17. Протисты: Руководство по зоологии / под ред. А. Ф. Алимова. СПб: Наука, 2007. Ч. 2. 1144 с.

18. Довгаль И. В. Инфузории. Суктории (Ciliophora, Suctorea) // Фауна Украины. Киев: «Наукова Думка», 2013. Т. 36.270 с.

19. Жариков В. В. Свободноживущие инфузории Волги: состав, динамика и пространственно-временное распределение в условиях полного гидротехничеСкого зарегулирования реки: дис. ... докт.биол.наук: 03.00.08. СПб., 1997. 403 с.

20. Foissner W. Protists as bioindicator in activated sludge: identification, ecology and future needs. European Journal of Protistology, 2016. Vol. 55. P. 75-94. 
21. Приходько А. В. Морфо-экологические особенности инфузорий из природных и антропогенных биоценозов Амурской области: дис. ... канд. биол. наук: 03.00.16. Хабаровск: ДВГУПС, 2009. 155 с.

22. Мамедова А. К. Фауна инфузорий в очистных сооружениях Говсаны и Сахиль Апшеронского полуострова // Австрийский журнал технических и естественных наук. 2016. № 3-4. C. 11-15.

23. Oberschmidleither R., Aescht E. Taxonomische Untersuchungen uber einige Ciliaten (Ciliophora, Protozoa) aus Belebtschlammen oberosterreichischer Klaranlagen // Beitrage zur Naturkunde Oberosterreichs. 1996. Bd.4. P. 3-30.

24. Шарапова И. В. Структура и пространственно-временная динамика населения биоценоза активного ила (в условиях биологической очистки стоков малого города): дис. ... канд. биол. наук: 03.00.08. Воронеж, 2010. 224 с.

25. Алекперов И. Х. Свободноживущие инфузории Азербайджана (экология, зоогеография, практическое значение). Баку: Эльм, 2012.520 с.

26. Трибун М. М. Инфузории реки Амур // Инновационные процессы в современной науке, тенденции развития: сб. статей межд. науч.-практ. конф. Уфа: Вестник науки. 2019. С. 145-149.

27. Цилиофауна природных и техногенных экосистем Среднего Приамурья: монография / Л. И. Никитина и др. Хабаровск: ДВГУПС, 2011. 160 с.

28. Быкова С. В. Фауна и экология инфузорий малых водоемов Самарской Луки и Саратовского водохранилища: дис. ... канд. биол. наук: 03.00.16. Тольятти, 2005. 207 C.

29. Жмур Н. С. Технологические и биохимические процессы очистки сточных вод на сооружениях с аэротенками. Москва: АКВАРОС, 2003. 512 с.

( ) Трибун Михаил Маркович ( tribunmikhail@gmail.com ), Жуков Андрей Валерьевич ( a.v.zhukov@mail.ru ).

Журнал «Современная наука: актуальные проблемы теории и практики»

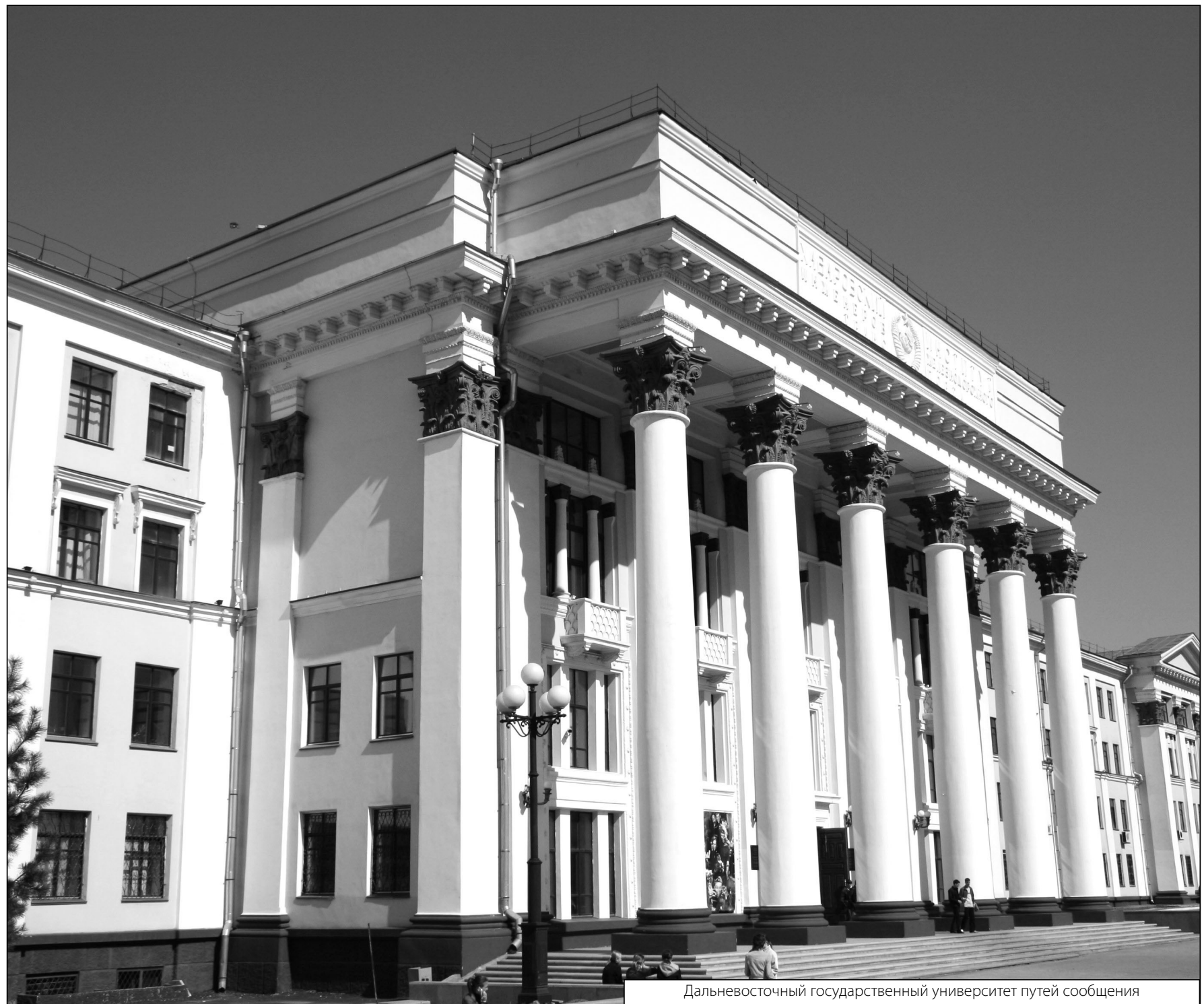

